\title{
Impact of Weed Control by Hand Tools on Soil Erosion under a No-Tillage System Cultivation
}

\author{
Rafael Blanco-Sepúlveda ${ }^{1, *(\mathbb{D}}$, Amilcar Aguilar-Carrillo ${ }^{2}$ and Francisco Lima ${ }^{1}$ \\ 1 Geographic Analysis Research Group, Department of Geography, Campus of Teatinos, University of Málaga, \\ 29071 Málaga, Spain; lima@uma.es \\ 2 Tropical Agricultural Research and Higher Education Centre (CATIE), CATIE 7170, \\ Turrialba 30501, Costa Rica; aaguilar@catie.ac.cr \\ * Correspondence: rblanco@uma.es
}

check for updates

Citation: Blanco-Sepúlveda, R.; Aguilar-Carrillo, A.; Lima, F. Impact of Weed Control by Hand Tools on Soil Erosion under a No-Tillage System Cultivation. Agronomy 2021 11, 974. https://doi.org/10.3390/ agronomy11050974

Academic Editor: Stéphane Cordeau

Received: 25 March 2021

Accepted: 11 May 2021

Published: 13 May 2021

Publisher's Note: MDPI stays neutral with regard to jurisdictional claims in published maps and institutional affiliations.

Copyright: (c) 2021 by the authors. Licensee MDPI, Basel, Switzerland. This article is an open access article distributed under the terms and conditions of the Creative Commons Attribution (CC BY) license (https:// creativecommons.org/licenses/by/ $4.0 /)$.

\begin{abstract}
In conservation agriculture, the no-tillage cultivation system and the retention of permanent vegetal cover are crucial to the control of soil erosion by water. This paper analyses the cultivation of maize under no-tillage, with particular reference to the effect produced on soil erosion when weed control is performed by a hand tool (machete), which disturbs the surface of the soil, and to the behavior of the soil cover in these circumstances. The study area is located in the humid tropical mountains of northern Nicaragua (Peñas Blancas Massif Nature Reserve). The results obtained show that $59.2 \%$ of the soil surface was affected by appreciable levels of sheet and splash erosion, although the vegetal cover of the soil was relatively high (with average weed and litter cover of $33.9 \%$ and $33.8 \%$, respectively). The use of machetes for weed control provoked considerable soil disturbance, which explained the high rates of erosion observed. Moreover, this form of soil management disturbs the litter layer, making it less effective in preventing erosion. The litter remains loose on the soil surface, and so an increase in soil cover does not achieve a proportionate reduction in the area affected by erosion; thus, even with $80-100 \%$ weed and litter cover, $42 \%$ of the cultivated area continued to present soil erosion.
\end{abstract}

Keywords: water erosion; conservation agriculture; no-tillage; weed control by hand tool; ground vegetal cover

\section{Introduction}

Maize (Zea mays L.) is considered a health-giving food [1] and is fundamental to the human diet in certain regions, such as Central America [2]. According to Food and Agriculture Organization (FAO) [3], the land surface area dedicated to the cultivation of maize in Central America increased at an average annual rate of $0.35 \%$ between 1961 and 2017 , to the current total area of 9.3 million ha. This expansion in the cultivated acreage has been accompanied by a parallel rise in productivity (annual average increase of $2.35 \%$, with crop yields improving from 974 to $2426 \mathrm{~kg} \mathrm{ha}^{-1}$ between 1961 and 2017). These advances are among the achievements of the "Green Revolution", which has intensified the productivity of cultivation systems in this region since the 1950s [4].

The cultivation of maize in Central America has been developed not only in the areas most suitable for agriculture but also in mountainous regions, where the expansion of cultivated lands has often been to the detriment of wooded and forested areas [5]. The tropical mountains are especially vulnerable to degradation, mainly due to soil erosion by water [6]. This degradation process may have severe economic and social consequences in the region. Soil erosion causes the loss of the most fertile soil layers and, consequently, their productive capacity is reduced [7], which constitutes a threat to the sustainability of small and medium agricultural producers who live in mountainous areas [8]. With climate change, the problem is expected to worsen in the coming decades [9]. 
The traditional cultivation system that continues to be practiced in many upland areas of Central America is based on no-tillage and on the presence of high rates of vegetal cover on the soil [10]. These features constitute the most important measures of conservation agriculture (CA) to reduce soil erosion by water [11]. With no-till, the soil structure remains intact, which makes it more resistant to splash dispersion and runoff [12]. In this regard, ground vegetal cover is of fundamental importance, for the following reasons: (1) it intercepts rainfall and reduces its kinetic energy, thus preventing the dispersion of soil aggregates; in addition, it slows runoff, which increases infiltration and reduces soil losses [13,14]; (2) the enrichment of organic matter, from the decomposition of vegetal residues and associated biological activities, improves structural stability and, consequently, increases the resistance to soil erosion $[15,16]$.

Analysis of the effectiveness of this culture system in reducing soil erosion is usually based on the joint study of these two key measures of conservation agriculture, because they are closely related; when no-tillage is practiced, a layer of vegetal residues is normally left on the soil surface [17]. The question addressed in this paper is: what happens when one of the conservation agriculture measures, namely no-tillage, is altered? This issue is of major importance, because the situation observed under the controlled conditions of experimental farmland may be quite different in the real-world context of private property, where crop management policies might not adhere to the guidelines established for conventional systems. It is essential to take into account all of the actions carried out during the crop cycle in order to ensure the effectiveness of conservation agriculture. In this respect, weed control is of special interest. This is one of the most important management practices in the agricultural cycle, with far-reaching implications for soil conservation. Therefore, to preserve the benefits of the CA system, weed control must be performed appropriately [18]. The traditional procedure, using manual tools such as hoes (with tillage systems) and machetes (with no-tillage systems), is common in Central America [19]. With a machete, the weeds are cut at ground level, but if this is not done correctly, i.e., if the tool makes contact with the ground, the resulting impact disturbs the structure of the soil surface. We believe this action may increase erosion, by modifying the favorable conditions provided by the no-tillage system.

In order to achieve a better understanding of the sustainable use of agricultural soils, we believe it necessary to examine the effectiveness of erosion control measures within conservation agriculture in situations altered by management practices. This is a key issue from the economic perspective. Crop productivity under conservation agriculture, in comparison with conventional tillage, has been studied. Different results have been obtained, but studies in which productivity has decreased under conservation agriculture, especially in tropical environments, have been predominant $[20,21]$. These results could even be aggravated if erosion increases as a result of poor agricultural management during the crop cycle. In view of these considerations, the present study has the following aims: (1) to analyze the influence on soil erosion by water when weed control is conducted by machete in no-tillage maize cultivation, disturbing the soil surface; (2) to determine the influence of vegetal cover in this situation.

\section{Materials and Methods}

\subsection{Site Characteristics}

The study was conducted in 2015 on sixteen sample plots of maize cultivation located in the buffer zone of the Peñas Blancas Massif Nature Reserve, in the departments of Jinotega $\left(13^{\circ} 5^{\prime} 18^{\prime \prime} \mathrm{N}, 85^{\circ} 59^{\prime} 57^{\prime \prime} \mathrm{W}\right)$ and Matagalpa $\left(12^{\circ} 55^{\prime} 44^{\prime \prime} \mathrm{N}, 85^{\circ} 54^{\prime} 54^{\prime \prime} \mathrm{W}\right)$ in Nicaragua (Figure 1). In the Massif, which forms part of the Bosawas Biosphere Reserve, the climate is tropical humid, with an average annual rainfall exceeding $2000 \mathrm{~mm}$ (2770 mm in El Cua, Jinotega, and $2414 \mathrm{~mm}$ in El Tuma-La Dalia, Matagalpa). The rainy season is from AprilMay to December-January. In addition, the study area is characterized by a high frequency of occurrence of extreme meteorological and climatic phenomena, such as hurricanes and tropical storms [22]. The mean annual air temperature ranges from 20 to $25^{\circ} \mathrm{C}$. The study 
farms presented slopes of $23-66 \%$ (average slope $42 \pm 3.8 \%$ ). The soils were classified as chromic Cambisols [23]. The soil texture is typically clay loam ( $25.4 \pm 1.8 \%$ clay, $26.6 \pm 2.2 \%$ fine silt, $17.0 \pm 2.7 \%$ coarse silt and $31.0 \pm 2.1 \%$ sand), with $3.9 \pm 0.3 \%$ organic carbon, $0.8 \pm 0.08 \%$ equivalent calcic carbonate, $41.8 \pm 2.5$ meq $100 \mathrm{gr}^{-1}$ cationic exchange capacity and $35.4 \pm 4.6 \%$ base saturation rate.

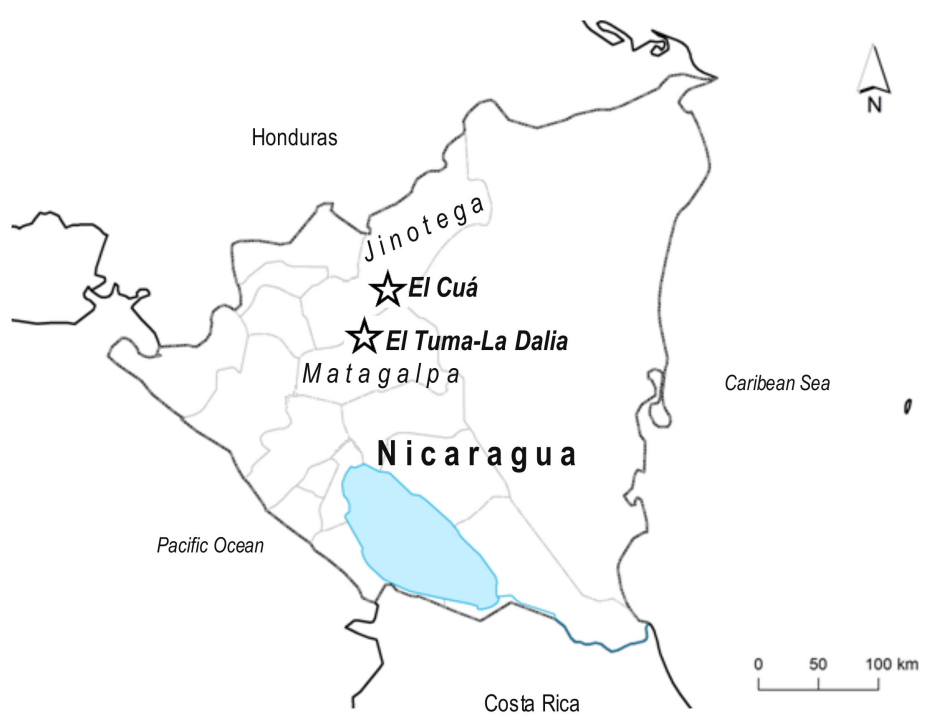

Figure 1. Location of the study area.

\subsection{Crop Management}

The agricultural system employed consists of a rotational cycle, with two crops, of maize and beans (Phaseolus vulgaris L.) (Figure 2). In this cycle, the maize is sown at the beginning of the rainy season, in April-May, and harvested in October-November. Then, at the end of the rainy season, beans are sowed in November-December, and harvested in February-March. In both cases, the sowing is conducted using a digging stick (espeque), and the technique is classed as no-till [24]. Sowing was performed at 0.8-1 m intervals along contour lines (rows) spaced 1.0-1.1 m apart. Weed control is performed twice yearly during maize cultivation (Figure 2), in the early stages of plant growth because this is when it is more sensitive to competition from weeds for resources (water and nutrients). Throughout the region, weed control is normally performed with machetes and herbicides. First, the weeds are removed using a machete, applied very superficially; in most cases, the tool makes contact with the soil surface, causing the first $2-3 \mathrm{~cm}$ of the soil structure to be disturbed. Smaller weeds may escape this mechanical action and therefore the control process is continued with the application of herbicide, usually paraquat or glyphosate.

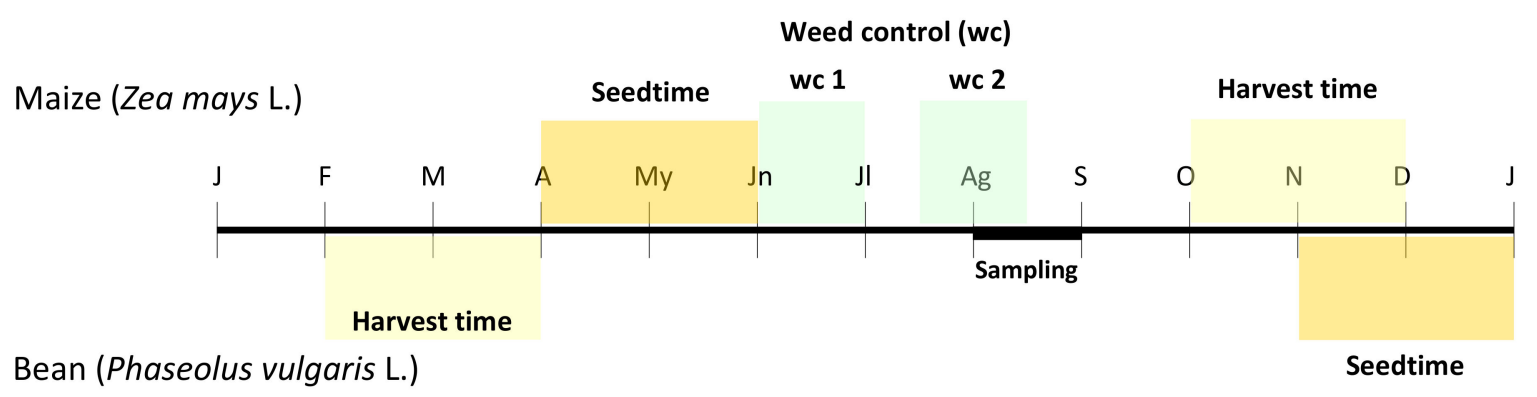

Figure 2. Maize-bean rotational cultivation system and sampling period.

Weeds are not controlled during bean cultivation because their development is limited by the arid conditions of the dry season. The most frequent fertilizer treatments are 
the application of NPK (15:15:15 or 18:46:0), during the first weed control, or of urea, twice yearly.

For the purposes of this study, samples were obtained during August, within 15 days of the second weed control.

\subsection{Soil Erosion Analysis and Calculation of Ground Vegetal Cover}

Sampling plots were selected by means of a previous work phase of recognition of the study area. This phase consisted in performing a survey of the area, farm by farm, in order to diagnose the erosive situations currently affecting the soil as the result of agricultural activity. The aim of this reconnaissance activity was to establish the research goals and to select representative plots in which to conduct the study. These plots were homogeneous in terms of the physical factors (mainly, slope gradient and soil type) that may influence erosion processes. Afterwards, the soil analyses confirmed that the study plots had homogeneous characteristics. The sampling was carried out after a rainy event, for which rain gauges were installed in the study area in order to plan the sampling work.

Soil erosion by water was analyzed using the method described by Blanco [25], who studied the erosive state of the soil (i.e., the percentage of land area affected by different types of erosion and by surface processes) and the soil loss (in $\mathrm{m}^{3} \mathrm{ha}^{-1}$ ). The erosive state was analyzed by an improved version of the Stocking and Murnaghan method [26], based on visual indicators of erosion. Soil loss was calculated by volumetric measurements of the rills and gullies [27]. Table 1 shows the types of erosion and the surface processes observed, coded by an index (capital letter) to indicate the type of process and by a subscript that provides complementary information, such as the type of erosion and type of protective vegetal cover.

Table 1. Processes and types of erosion affecting soil in the cultivation of maize (adapted from Blanco [25]).

M. Mechanical Soil Disturbance By Tool (Machete), Affected By Erosion, or
Erosion-Susceptible

T. Mechanical soil disturbance by trampling, affected by erosion, or erosion-susceptible

1. (Tes) Soil disturbed by trampling and susceptible to erosion (but not visible at present) 2. (Ti/Ts/Tr/Tg) Soil disturbed by trampling and affected by splash erosion/by sheet erosion/by erosion in rills/by erosion in gullies

\section{Soil deposition affected by erosion or erosion-susceptible}

1. (Des) Soil deposition susceptible to erosion (but not visible at present)

2. (Di/Ds/Dr/Dg) Soil deposition affected by splash erosion/by sheet erosion/by erosion in rills/by erosion in gullies

\begin{tabular}{c}
\hline N. No erosion \\
\hline $\begin{array}{c}\text { 1. }(\mathrm{Nw}) \text { No evidence of erosion beneath cover of weeds } \\
\text { 2. (Nl) No evidence of erosion beneath litter layer }\end{array}$ \\
\hline O. Others \\
\hline $\begin{array}{c}\text { 1. (Or) Stones } \\
\text { 2. (Oa) Animals: tracks, feces, carcasses, others. }\end{array}$ \\
\hline
\end{tabular}

A line transect sampling method was used to analyze the area affected by erosion, to calculate the level of ground cover and, using grids, to determine the volume of soil loss. For each sampling plot, three transects and three grids were established, at random, as described in Figure 3 and its accompanying text. 


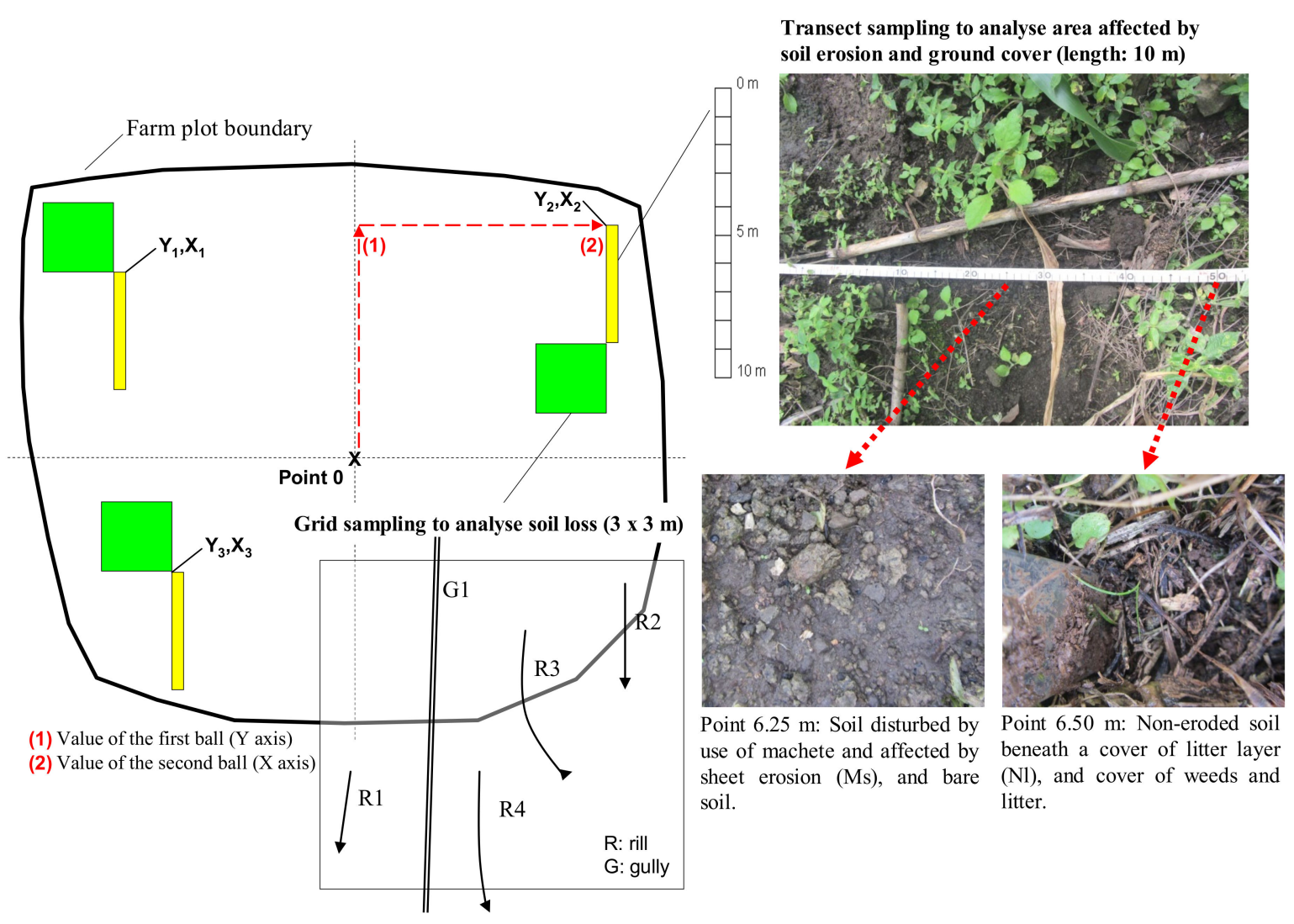

Figure 3. Sampling procedure to establish soil erosion and ground cover (adapted from Blanco [25]). The transects and grid squares originated from point 0 in the sample plot. The distances of the $x-y$ axes were randomly determined by the blind extraction of numbered balls. Each transect was $10 \mathrm{~m}$ long and samples were taken at $25 \mathrm{~cm}$ intervals (in total, there were 40 observation points of the erosion indicators and of ground cover per transect, i.e., 120 observations were made per plot, and 1920 in the total of the 16 plots studied). The grid squares measured $3 \times 3 \mathrm{~m}$ and were used to measure the length, width and depth of all the rills and gullies present.

\subsection{Research Design and Statistical Analysis}

In the present study, a non-experimental explanatory sequential mixed method was used, following Creswell [28]. In this two-step approach, both quantitative and qualitative analyses were performed. In the first step, the quantitative analysis, the results were examined by tests of bivariate correlation (Spearman correlation coefficient, rho) and by analysis of the variance (the Kruskal-Wallis test). These analyses were conducted using IBM SPSS 25.0 software (IBM Corp, Armonk, NY, USA). The subsequent, qualitative, phase involved field observation of the visual indicators of the study event, seeking a more detailed understanding of the results obtained by the quantitative analysis.

In this study, it was not possible to apply an experimental research design because the necessary circumstances for this did not exist: (a) on the one hand, the crop management system in the study area was homogeneous, and so there were no cases in which weed control was carried out differently from that described; (b) furthermore, the study area consisted of small farms, whose owners were very reluctant to cede part of their land for experimental research.

\section{Results}

\subsection{The State of Soil Erosion and the Ground Cover}

In the maize crops studied, the mean area affected by erosion (Et) was $59.2 \pm 5.0 \%$ (Table 2). The main types of erosion observed in soils that had previously been disturbed by the use of machetes for weed control were sheet erosion (Ms) $(33.3 \pm 4.4 \%)$ and splash erosion (Mi) $(24.6 \pm 5.9 \%)$. The other processes affecting the soil (trampling and deposition) 
had little perceptible influence on erosion. The crop area that remained unaffected by erosion (Ene) was $37.2 \pm 5.3 \%$. The two types of land cover (weeds and vegetal residue) are assumed to provide the same degree of protection against soil erosion, as the same rates of erosion were observed in both cases: $13.5 \pm 2.5 \%$ in soils protected by weed cover $(\mathrm{Nw})$ and $13.7 \pm 2.7 \%$ in those protected by a layer of plant litter (Nl). No soil losses in the form of rills or gullies were observed.

Table 2. Processes and types of soil erosion by water in maize cultivation plots $(n=16)$.

\begin{tabular}{|c|c|c|}
\hline Processes and Water Erosion Types & Abbreviation & Mean \pm Standard Error \\
\hline $\begin{array}{l}\text { Soil disturbed by machete and susceptible to erosion } \\
\text { (but no erosion currently visible) (\%) }\end{array}$ & Mes & $9.6 \pm 2.4$ \\
\hline $\begin{array}{l}\text { Soil disturbed by tool use and affected by splash } \\
\text { erosion (\%) }\end{array}$ & $\mathrm{Mi}$ & $24.6 \pm 5.9$ \\
\hline $\begin{array}{l}\text { Soil disturbed by tool use and affected by sheet } \\
\text { erosion (\%) }\end{array}$ & Ms & $33.3 \pm 4.4$ \\
\hline $\begin{array}{l}\text { Soil disturbed by trampling and susceptible to erosion } \\
\text { (but no erosion currently visible) }(\%)\end{array}$ & Tes & $0.3 \pm 0.2$ \\
\hline $\begin{array}{l}\text { Soil disturbed by trampling and affected by splash } \\
\text { erosion (\%) }\end{array}$ & $\mathrm{Ti}$ & $0.2 \pm 0.1$ \\
\hline $\begin{array}{l}\text { Soil disturbed by trampling and affected by sheet } \\
\text { erosion (\%) }\end{array}$ & Ts & $1.0 \pm 0.4$ \\
\hline Soil deposition affected by splash erosion (\%) & Di & $0.1 \pm 0.1$ \\
\hline No evidence of erosion beneath cover of weeds (\%) & $\mathrm{Nw}$ & $13.5 \pm 2.5$ \\
\hline No evidence of erosion beneath litter layer $(\%)$ & $\mathrm{Nl}$ & $13.7 \pm 2.7$ \\
\hline Other topsoil characteristics (stones) $(\%)$ & Or & $3.6 \pm 1.3$ \\
\hline Total area affected by soil erosion (\%) & Et & $59.2 \pm 5.0$ \\
\hline Total area not affected by soil erosion (\%) & Ene & $37.2 \pm 5.3$ \\
\hline Soil loss $\left(\mathrm{m}^{3} \mathrm{ha}^{-1}\right)$ & Esl & 0 \\
\hline
\end{tabular}

The mean level of ground cover in the maize crops studied was $67.7 \pm 4.2 \%$, divided equally between weeds $(33.9 \pm 5.7 \%)$ and vegetal residues (33.8 \pm 4.7$)$ (Table 3). Weed control with machetes did not produce soil inversion, and so high rates of ground cover were maintained. However, the impact of the machete on the ground, as well as disturbing the soil, reduced the stability of the litter layer. These residues continued to be present on the soil surface, but in most cases were loosened, and thus became more susceptible to runoff (Figure 4).

Table 3. Ground cover in maize cultivation plots $(n=16)$.

\begin{tabular}{ccc}
\hline Characteristics & Abbreviation & Mean \pm Standard Error \\
\hline $\begin{array}{c}\text { Ground cover by weeds (\%) } \\
\text { Ground cover by litter (\%) }\end{array}$ & $\mathrm{GC}_{\mathrm{W}}$ & $33.9 \pm 5.7$ \\
\hline $\begin{array}{c}\text { Total ground cover (weeds } \\
\text { and litter) }(\%)\end{array}$ & $\mathrm{GC}_{\mathrm{L}}$ & $33.8 \pm 4.7$ \\
\hline
\end{tabular}



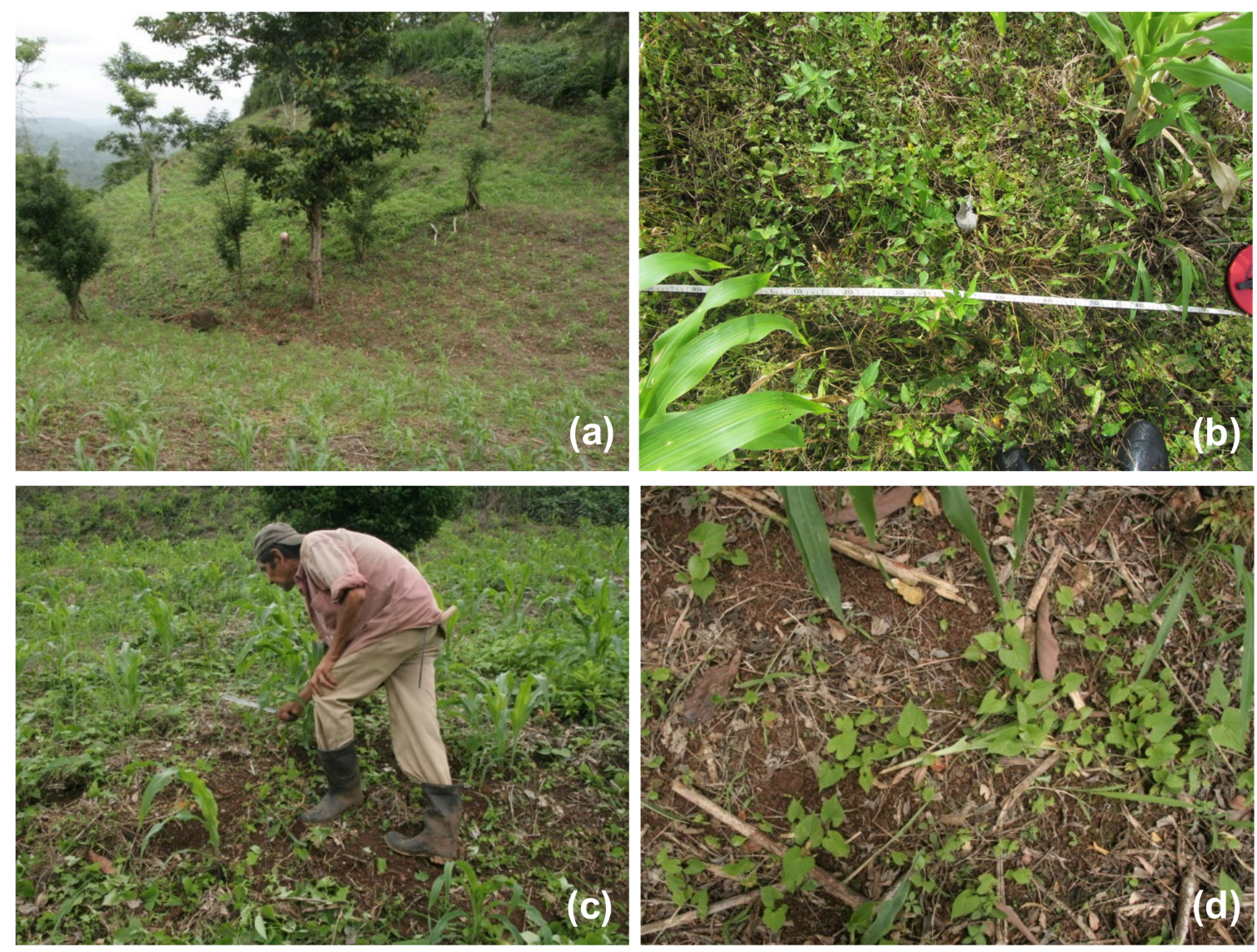

Figure 4. Visual indicators of the reduced stability of the litter layer after weed control: view of the whole plot (a); detail of the ground before weed control (b); weed control with machete (c); detail of the aspect after weed removal, with vegetal residues loose on the surface $(\mathbf{d})$.

\subsection{Influence of Ground Cover on Soil Erosion}

The correlation analysis performed revealed no relationship between soil erosion and ground cover (GC). The surface area affected by erosion did not present any significant correlation with GC by weeds (rho $=-0.20, p=0.457$ ), with GC by litter (rho $=-0.20$, $p=0.460)$ or with total GC (rho $=-0.27, p=0.304)($ Table 4$)$.

Table 4. Correlation between soil erosion and ground cover of the maize cultivation plots $(n=16)$.

\begin{tabular}{ccccc}
\hline & $\mathbf{E t}$ & $\mathbf{G C}_{\mathbf{W}}$ & $\mathbf{G C}_{\mathbf{L}}$ & $\mathbf{G C}_{\mathbf{W}-\mathbf{L}}$ \\
\hline \multirow{2}{*}{$\mathrm{Et}$} & 1 & -0.20 & -0.20 & -0.27 \\
& & $(p=0.457)$ & $(p=0.460)$ & $(p=0.304)$ \\
$\mathrm{GC}_{\mathrm{W}}$ & 1 & -0.67 & 0.54 \\
& & $(p=0.004)$ & $(p=0.003)$ \\
$\mathrm{GC}_{\mathrm{L}}$ & & 1 & 0.07 \\
$\mathrm{GC}_{\mathrm{W}-\mathrm{L}}$ & & & $(p=0.795)$ \\
$\mathrm{T}$ & & & 1
\end{tabular}

Et: Total area affected by soil erosion; $\mathrm{GC}_{\mathrm{W}}$ : ground cover by weeds; $\mathrm{GC}_{\mathrm{L}}$ : ground cover by litter; $\mathrm{GC}_{\mathrm{W}-\mathrm{L}}$ : total ground cover (sum of weeds and litter).

Graphical analysis of the erosion behavior, according to GC intervals by weeds and litter, showed that erosion decreased slightly as GC increased (Figure 5). Thus, soil erosion fell from $65.5 \%$ to $54.7 \%$ when GC by weeds increased by $60 \%$, and from $64.3 \%$ to $51.7 \%$ with a $60 \%$ increase in GC by litter. A larger decrease was only achieved when weed and litter cover were considered jointly. Then, erosion fell from $58.7 \%$ to $41.9 \%$ when total GC 
increased from $40 \%$ to $100 \%$. However, the erosion reduction observed with increased GC was insufficient for statistically significant differences to become apparent. Analysis of variance showed there were no significant differences in erosion between the different intervals of ground cover, in any of the situations studied as a clustering variable: GC by weeds (chi-square $=1.35, p=0.509$ ), GC by litter (chi-square $=0.62, p=0.735$ ) and total GC $($ chi-square $=2.11, p=0.348)($ Table 5$)$.
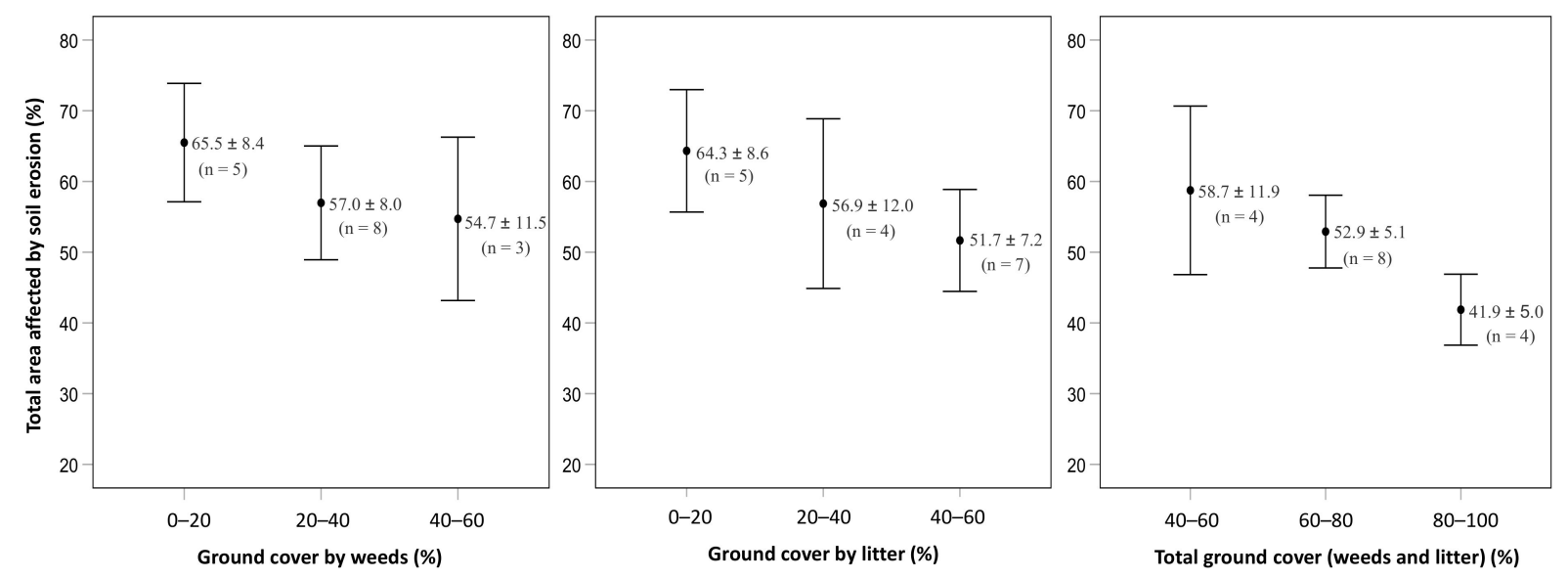

Figure 5. Extent of soil affected by erosion in relation to ground cover in maize cultivation plots. Values are mean \pm standard error.

Table 5. Kruskal-Wallis test of the relation between erosion and ground cover in maize cultivation plots $(n=16)$.

\begin{tabular}{|c|c|c|}
\hline Ground Cover Types & $\begin{array}{l}\text { Cover Intervals (\%) } \\
\text { (n for Each Interval) }\end{array}$ & Results \\
\hline Ground cover by weeds & $\begin{array}{c}0-20,20-40,40-60 \\
(\mathrm{n}=5,8,3)\end{array}$ & Chi-square $=1.35, p=0.509$ \\
\hline Ground cover by litter & $\begin{array}{c}0-20,20-40,40-60 \\
(\mathrm{n}=5,4,7)\end{array}$ & Chi-square $=0.62, p=0.735$ \\
\hline $\begin{array}{c}\text { Total ground cover (weeds } \\
\text { and litter) }\end{array}$ & $\begin{array}{c}40-60,60-80,80-100 \\
(\mathrm{n}=4,8,4)\end{array}$ & Chi-square $=2.11, p=0.348$ \\
\hline
\end{tabular}

\section{Discussion}

The study results obtained show that the sample plots were subject to the effects of sheet and splash erosion, but there was no loss of soil in the form of rills and gullies. When soil is disturbed it loses cohesion and this may favor the concentration of runoff water [29]. For this reason, we hypothesized that disturbing the soil with a machete during weed control might result in the formation of rills and gullies. In the study area, however, this disturbance was only superficial, affecting the first $2-3 \mathrm{~cm}$, and did not invert the soil mass, and so the vegetal cover was not incorporated into the soil. In consequence, the level of GC remained relatively high, impeding the concentration of runoff and the formation of rills and gullies. Prosdocimi et al. [30] analyzed the role of litter cover on erosion and concluded that this factor is very effective in reducing surface runoff and in increasing water infiltration into the soil, which reduces its susceptibility to erosion via rills and gullies.

No correlation was observed between the ground cover and the water erosion. For this reason, even when the level of GC was relatively high, soil disturbance leads to a considerable area of the soil surface being affected by splash and sheet erosion. Disturbed soil is less resistant to the impact of rainfall [31], which accounts for a large proportion of the soil surface affected by splash erosion $(24.8 \%)$. Weed cover is known to protect the soil against this impact [32], but it is not as effective against runoff, in which case litter cover plays a more significant role [19]. Weed control by machete disturbed not only the soil, but 
also the litter layer, reducing its effectiveness in preventing sheet erosion. Vegetal residues must not only be present but also stable on the soil surface, and our study showed that the management of ground cover with the use of machetes disturbed and loosened the litter layer, thus reducing its effectiveness in preventing erosion. Under these circumstances, it can be understood why water erosion did not show a correlation with soil cover. A comparison of our results with those obtained in a previous study is illustrative of this consideration. In the sample plots considered in this study, with GC by litter of 33.8\%, the surface area affected by sheet erosion (Ms and Ts) was $34.3 \%$, whereas $13.7 \%$ of the area under plant litter $(\mathrm{Nl})$ was not subject to erosion. This finding contrasts with that obtained by Blanco and Aguilar [33] in a study of bean cultivation with a no-till system in the same area as that addressed in the present study (hence, the environmental conditions were the same). Moreover, rainfall patterns were similar during the sampling periods of both investigations. In the early study, only $1.9 \%$ of the study area was affected by sheet erosion, whereas $36.2 \%$ of the area under plant litter was unaffected by erosion, 22.5 percentage points more than in our case, despite the similar level of litter cover (35.4\%).

Our study results show that the ground vegetal cover arising from the type of soil management performed, i.e., the greater presence of weed cover and litter, did not reduce the area of soil affected by erosion in the same proportion. Weed and litter cover, considered individually, did not reduce the area affected by erosion to below $50 \%$, despite GC levels of up to $60 \%$. Even when GC (weed and litter) reached $100 \%$, the area affected by erosion only decreased to $42 \%$. These results are far from those obtained by Blanco and Aguilar [33], in whose study of no-tillage bean cultivation the presence of $65 \%$ of litter cover reduced the area affected by erosion to around $20 \%$.

The findings presented in this paper clarify the role played by ground cover, both that of living plants and that of vegetal residues, in protecting the soil from erosion. Previous research in this field has shown that, apart from GC, erosion is subject to various other influences $[30,34]$ that should be taken into account in order to achieve effective erosion control. Our results demonstrate that the litter layer in itself did not protect the soil from erosion; this contrasts with previous reports [33,35-38]. In fact, the disturbance of the surface structure of the soil when weed control is carried out by machete is the factor that really prevented effective erosion control, even when the litter layer covered $60 \%$ of the soil surface, a value that rises to $100 \%$ when the weed cover is also taken into account.

Undoubtedly, the GC factor is important, but it seems that this is not enough. Our results show that the soil structure must remain undisturbed if effective erosion control is to be achieved. Arshad et al. [39] and Zhang et al. [40] corroborate this view, concluding that low rates of erosion are observed in crops with no-tillage systems due to their greater structural stability and the greater macroporosity of the surface when the soil structure remains intact. These conditions favor the hydrological properties of the soil, thus facilitating infiltration and reducing soil losses. In this regard, Lal [41] emphasized the importance of employing appropriate techniques of soil management in order to avoid disturbing the soil surface. For this study area, we suggest the use of very sharp machetes, with a cutting angle as parallel as possible to the ground surface. To facilitate accurate cutting, the farmer can use a stick that can serve as a guide to lift the weeds and open the spaces for cutting. In this way, disturbing the soil surface could be avoided. A video is attached (link: https:/ / youtu.be/vogi8ktZs6o [42]) that illustrates the use of a machete for weed control in coffee crops with an adequate cutting angle and the support of a stick guide. This handling procedure can be perfectly adapted to maize cultivation.

\section{Conclusions}

Our study results show that weed control with machetes is the decisive factor in explaining the large area of the sample plots affected by erosion (59.2\%). The positive effects of no-tillage cultivation on erosion control are annulled by the soil disturbance produced by the use of machetes, and the influence of the ground cover is insufficient to counteract this outcome. Thus, a high proportion of the land area continued to be affected 
by erosion: $57 \%$ with litter cover of up to $60 \%$, and $42 \%$ with litter and weed cover of up to $100 \%$. These figures are far from those reported in a previous study of no-tillage cultivation, without soil disturbance in the weed control process, in which $20 \%$ of the total area was affected by erosion when the level of litter cover was $65 \%$. When machetes are used in weed control, loose residues are deposited on the soil surface and its capacity to prevent erosion is reduced. For this reason, no correlation was observed between the increased proportion of ground cover and the reduction in erosion.

The study results presented in this paper show that the effectiveness of conservation agriculture in controlling erosion depends on the simultaneous maintenance of two conditions: not disturbing the soil structure and maintaining high levels of ground cover. When the first condition ceases to apply, the second, by itself, is unable to control erosion.

Author Contributions: R.B.-S. and A.A.-C. designed the research framework and contributed to the application of the study methodology and the analysis of the results. R.B.-S. and F.L. played an active role in writing, reviewing and editing the manuscript. All authors have read and agreed to the published version of the manuscript.

Funding: This study was performed within the framework of the International University Volunteering in Cooperation for Development project (funded by UMA-AACID), in collaboration with the Tropical Agricultural Research and Higher Education Centre (CATIE). It also forms part of the project Participatory Development of Alternative Sustainable Uses for Degraded Pastures in Central America, financed by the Norwegian Ministry of Foreign Affairs. In addition, the University of Málaga (Spain) provided financial support for this study, through its 1st Research and Transfer Plan.

Institutional Review Board Statement: Not applicable.

Informed Consent Statement: Not applicable.

Data Availability Statement: Not applicable.

Conflicts of Interest: The authors declare no conflict of interest.

\section{References}

1. Development Initiatives. Global Nutrition Report: Shining a Light to Spur Action on Nutrition; Development Initiatives Poverty Research Ltd.: Bristol, UK, 2018; Available online: https://www.who.int/nutrition/globalnutritionreport/2018_Global_Nutrition_ Report.pdf (accessed on 17 September 2020).

2. FAO. The State of Food-Based Dietary Guidelines in Latin America and the Caribbean; FAO: Rome, Italy, 2014; Available online: http:/ / www.fao.org/3/a-i3677s.pdf (accessed on 5 July 2020). (In Spanish)

3. FAO. Food and Agriculture Organization of the United Nations, FAOSTAT. 2020. Available online: http://www.fao.org/faostat/ en/\#data/QC (accessed on 14 September 2020).

4. Piñeiro, M.; Trigo, E.; Fiorentino, R. Technical change in Latin American agriculture. Food Policy 1979, 4, 169-177. [CrossRef]

5. Zeledon, E.B.; Kelly, N.M. Understanding large-scale deforestation in southern Jinotega, Nicaragua from 1978 to 1999 through the examination of changes in land use and land cover. J. Environ. Manag. 2009, 90, 2866-2872. [CrossRef]

6. Wantzen, K.M.; Mol, J.H. Soil Erosion from Agriculture and Mining: A Threat to Tropical Stream Ecosystems. Agriculture 2013, 3 , 660-683. [CrossRef]

7. Lal, R. Soil erosion impact on agronomic productivity and environment quality. Crit. Rev. Plant Sci. 1988, 17, 319-464. [CrossRef]

8. Öborn, I.; Vanlauwe, B.; Atta-Krah, K.; Thomas, T.; Phillips, M.; Schut, M. Integrated systems research for sustainable intensification of smallholder agriculture. In Sustainable Intensification in Smallholder Agriculture: An Integrated Systems Research Approach; Öborn, I., Atta-Krah, K., Phillips, M., Thomas, R., Vanlauwe, B., Brooijmans, W., Eds.; Routledge: London, UK; New York, NY, USA, 2017; pp. 32-46.

9. Kang, M.S.; Banga, S.S. Global agriculture and climate change. J. Crop Improv. 2013, 27, 667-692. [CrossRef]

10. Lal, R. Tillage systems in the tropics. In Management Options and Sustainability Implications; FAO Soils Bulletin No. 71; FAO: Roma, Italy, 1995.

11. Evans, R. Sustainable practices to limit soil erosion: A review and discussion. Cab Rev. 2006, 1, 1-12. [CrossRef]

12. Reicosky, D.C.; Saxton, K.E. The benefits of no-tillage. In No-Tillage Seeding in Conservation Agriculture; Baker, C.J., Saxton, K.E., Eds.; FAO and CAB International: Roma, Italy, 2007; pp. 11-20.

13. Bradford, J.M.; Huang, C. Interrill soil erosion as affected by tillage and residue cover. Soil Tillage Res. 1994, 31, 353-361. [CrossRef]

14. Mondal, S.; Chakraborty, D.; Bandyopadhyay, K.; Aggarwal, P.; Rana, D.S. A global analysis of the impact of zero-tillage on soil physical condition, organic carbon content, and plant root response. Land Degrad. Dev. 2020, 31, 557-567. [CrossRef] 
15. Carr, P.M.; Gramig, G.G.; Liebig, M.A. Impacts of organic zero tillage systems on crops, weeds, and soil quality. Sustainability 2013, 5, 3172-3201. [CrossRef]

16. Chowdhury, S.; Farrell, M.; Butler, G.; Bolan, N. Assessing the effect of crop residue removal on soil organic carbon storage and microbial activity in a no-till cropping system. Soil Use Manag. 2015, 31, 384-396. [CrossRef]

17. FAO. Soil Erosion: The Greatest Challenge to Sustainable Soil Management; FAO: Rome, Italy, 2019; Available online: http:/ / www.fao. org/3/ca4395en/ca4395en.pdf (accessed on 10 March 2020).

18. Sims, B.; Corsi, S.; Gbehounou, G.; Kienzle, J.; Taguchi, M.; Friedrich, T. Sustainable weed management for conservation agriculture: Options for smallholder farmers. Agriculture 2018, 8, 118. [CrossRef]

19. Blanco, R.; Enríquez, F. Erosion control in the sustainable cultivation of maize (Zea mays L.) and beans (Phaseolus vulgaris L.) at two stages of the agricultural cycle in Southern Guatemala. Sustainability 2018, 10, 4654.

20. Pittelkow, C.M.; Linquist, B.A.; Lundy, M.E.; Liang, X.; Van Groenigen, K.J.; Lee, J.; Van Gestel, N.; Six, J.; Venterea, R.T.; Van Kessel, C. When does no-till yield more? A global meta-analysis. Field Crop. Res. 2015, 183, 156-168. [CrossRef]

21. Kornecki, T.S.; Price, A.J. Management of High-Residue Cover Crops in a Conservation Tillage Organic Vegetable On-Farm Setting. Agronomy 2019, 9, 640. [CrossRef]

22. Magrin, G.O.; Marengo, J.A.; Boulanger, J.P.; Buckeridge, M.S.; Castellanos, E.; Poveda, G.; Scarano, F.R.; Vicuña, S. Central and South America. In Climate Change 2014: Impacts, Adaptation, and Vulnerability. Part B: Regional Aspects; Contribution of Working Group II to the Fifth Assessment Report of the Intergovernmental Panel on Climate Change; Barros, V.R., Field, C.B., Dokken, D.J., Mastrandrea, M.D., Mach, K.J., Bilir, T.E., Chatterjee, M., Ebi, K.L., Estrada, Y.O., Genova, R.C., Eds.; Cambridge University Press: Cambridge, UK; New York, NY, USA, 2014; pp. 1499-1566.

23. FAO-ISRIC-ISSS. World Reference Base for Soil Resources; World Soil Resources Reports No. 84; FAO: Rome, Italy, 1998; Available online: http:/ / www.fao.org/3/W8594E/w8594e00.htm (accessed on 17 September 2015).

24. FAO. Manual on Integrated Soil Management and Conservation Practices; Land and Water Bulletin No. 8; FAO: Rome, Italy, 2000; Available online: http:/ / www.fao.org/3/x4799e/x4799e.pdf (accessed on 21 January 2019).

25. Blanco, R. An erosion control and soil conservation method for agrarian uses based on determining the erosion threshold. MethodsX 2018, 5, 761-772. [CrossRef]

26. Stocking, M.; Murnaghan, N. Handbook for the Field Assessment of Land Degradation; Earthscan Pub. Ltd.: London-Sterling, UK, 2001.

27. Hudson, N.W. Field Measurement of Soil Erosion and Runoff; FAO Soils Bulletin: Rome, Italy, 1993.

28. Creswell, J.W. Research Design. Qualitative, Quantitative, and Mixed Methods Approaches, 4th ed.; SAGE Publications, Inc.: Thousand Oaks, CA, USA, 2014.

29. Poesen, J.; Nachtergaele, J.; Verstraeten, G.; Valentin, C. Gully erosion and environmental change: Importance and research needs. Catena 2003, 50, 91-133. [CrossRef]

30. Prosdocimi, M.; Tarolli, P.; Cerdà, A. Mulching practices for reducing soil water erosion: A review. Earth-Sci. Rev. 2016, 161, 191-203. [CrossRef]

31. Farres, P.J. The dynamics of rainsplash erosion and the role of soil aggregate stability. Catena 1987, 14, 119-130. [CrossRef]

32. Van Dijk, P.M.; Van der Zijp, M.; Kwaad, F.J.P.M. Soil erodibility parameters under various cropping systems of maize. Hydrol. Process. 1996, 10, 1061-1067. [CrossRef]

33. Blanco, R.; Aguilar, A. The erosion threshold for a sustainable agriculture in cultures of bean (Phaseolus vulgaris L.) under conventional tillage and no-tillage in Northern Nicaragua. Soil Use Manag. 2016, 32, 368-380. [CrossRef]

34. García-Ruiz, J.M.; Beguería, S.; Nadal-Romero, E.; Gonzalez-Hidalgo, J.C.; Lana-Renault, N.; Sansjuan, Y. A meta-analysis of soil erosion rates across the world. Geomorphology 2015, 239, 160-173. [CrossRef]

35. Derpsch, R.; Sidiras, N.; Roth, C.H. Results of studies made from 1977 to 1984 to control erosion by cover crops and no-tillage techniques in Parana, Brazil. Soil Tillage Res. 1986, 8, 253-263. [CrossRef]

36. Smith, G.D.; Coughlan, K.J.; Yule, D.F.; Laryea, K.B.; Srivastava, K.L.; Thomas, N.P.; Cogle, A.L. Soil management options to reduce runoff and erosion on a hardsetting Alfisol in the semi-arid tropics. Soil Tillage Res. 1992, 25, 195-215. [CrossRef]

37. Leys, A.; Govers, G.; Gillijns, K.; Berckmoes, E.; Takken, I. Scale effects on runoff and erosion losses from arable land under conservation and conventional tillage: The role of residue cover. J. Hydrol. 2010, 390, 143-154. [CrossRef]

38. Prosdocimi, M.; Jordán, A.; Tarolli, P.; Keesstra, S.; Novara, A.; Cerdà, A. The immediate effectiveness of barley straw mulch in reducing soil erodibility and surface runoff generation in Mediterranean vineyards. Sci. Total Environ. 2016, 547, 323-330. [CrossRef]

39. Arshad, M.A.; Franzluebbers, A.J.; Azooz, R.H. Components of surface soil structure under conventional and no-tillage in northwestern Canada. Soil Tillage Res. 1999, 53, 41-47. [CrossRef]

40. Zhang, G.S.; Chan, K.Y.; Oates, A.; Heenan, D.P.; Huang, G.B. Relationship between soil structure and runoff/soil loss after 24 years of conservation tillage. Soil Tillage Res. 2007, 92, 122-128. [CrossRef]

41. Lal, R. Soils and sustainable agriculture. A review. Agron. Sustain. Dev. 2008, 28, 57-64. [CrossRef]

42. Blanco, R. Video Weed-Control Coffee. Available online: https:/ / youtu.be/vogi8aktZs6o (accessed on 5 May 2021). 